Zoran Jovanović

University of Megatrend, Belgrade,

Faculty of Management, Zaječar ${ }^{1}$
SCIENTIFIC REVIEW ARTICLE doi:10.5937/ekonomika1502143J

Received: April 10, 2015

Accepted: May 16, 2015

\title{
MANAGEMENT AND CHANGES IN BUSINESS ENVIRONMENT
}

\begin{abstract}
This study emphasizes the need for managers to promptly and effectively respond to changing business environment. Also, special review on limiting factors in the activities of managers and limiting their ability to anticipate and respond to the challenges of change in the business environment. This study also suggests some ways in which managers and organizations might improve own readiness and flexibility which is needed to respond promptly to business environmental changes. Different types of organizational learning and their relationship to strategy formulation and implementation are described in this study.
\end{abstract}

Keywords: management, organization, business environment, organizational learning, changes.

JEL classification: M21, M54

\section{МЕНАЏМЕНТ И ПРОМЕНЕ У ПОСЛОВНОМ ОКРУЖЕЊУ}

\section{Апстракт}

У раду се апострофира потреба да менацери парвовремено и ефектно реагују у променљивом пословном окружеюу. Такође, посебан осврт је дат на ограничавајуће чиниоце у деловању руководиоца и сужавању њихових могућности да предвиде и одговоре на изазове промена у свом пословном окружењу. У раду се предлажу начини на које би менамери и организачије могли унапредити сопствену спремност и флексибилност која је потребна да се брзо одговори на пословне промене у окружеюу. Сви ови предлози су на неки начин повезани са управљачким и организачионим учењем, тако да ова студија дескрибује различите врсте организационог учења и нихов однос према формулисању и спровођењу стратегије.

Кључнеречи: менаџмент, организација, пословно окружење, организационо учење, промене.

1 zojo38@yahoo.com 


\section{Introduction}

It is a fact that nearly all business environments are in a state of ongoing change or disequilibrium. Companies must either stay aligned with changes in their competitive environments and react to these changes promptly, or actively anticipate changes in customer demographic, future technologies, and potential new products and services and thereby recreate their industries. It should be noted that industry changes are requesting answers from companies, especially entrepreneurial ones, for them to use the chance to reshape themselves as well as their branch of business.

The risk of falling out of step with industry changes will almost certainly increase in the future as competition intensifies; with existing and new technologies continue to be exploited. Changes in consumer demographics lead to new customer needs. Organizational change will, therefore, be essential to companies' survival. Organizational change management and transformation have become permanent features of the business landscape. In fact, strategic management might more appropriately be called "strategic change management".

\section{Limiting factors and anticipations}

There are many limiting business factors. This paper focuses on spotting key factors that limit manager capabilities for them to be discovered and to shorten their reach in the environment (Kanton, 2009, p.16). Also, there are some of the organizational and industry factors that are limiting the responsiveness of managers and their firms to environmental change.

Consolidating what is learned from the current change to help the company improve the change process in the future. If you want to avoid a long and heavy adaptation process you must improve your capacity to anticipate and prepare for future change. The ability to anticipate is the key ingredients of efficient speed and change management.

\section{Business environment and managers}

Practice has shown that managers in many cases fail to anticipate or adequately respond to change for a number of reasons. It happens that, managers simply do not notice change in their business environments. As a result, they are blinded by the changes that have occurred quite unexpectedly. Certain research has also shown that managers can be aware of changes in their industries, but they may fail to interpret these changes correctly. They often underestimate the importance of these changes, and they may wait too long to respond, or may not respond at all. Research has also shown that those managers that correctly notice changes can even correctly interpret the possible impact of these industry changes, but they might still fail to adopt an appropriate course of action. Relationship between firms and the competitive environment is illustrated in Figure 1. 
Figure 1: Model of Strategic Management

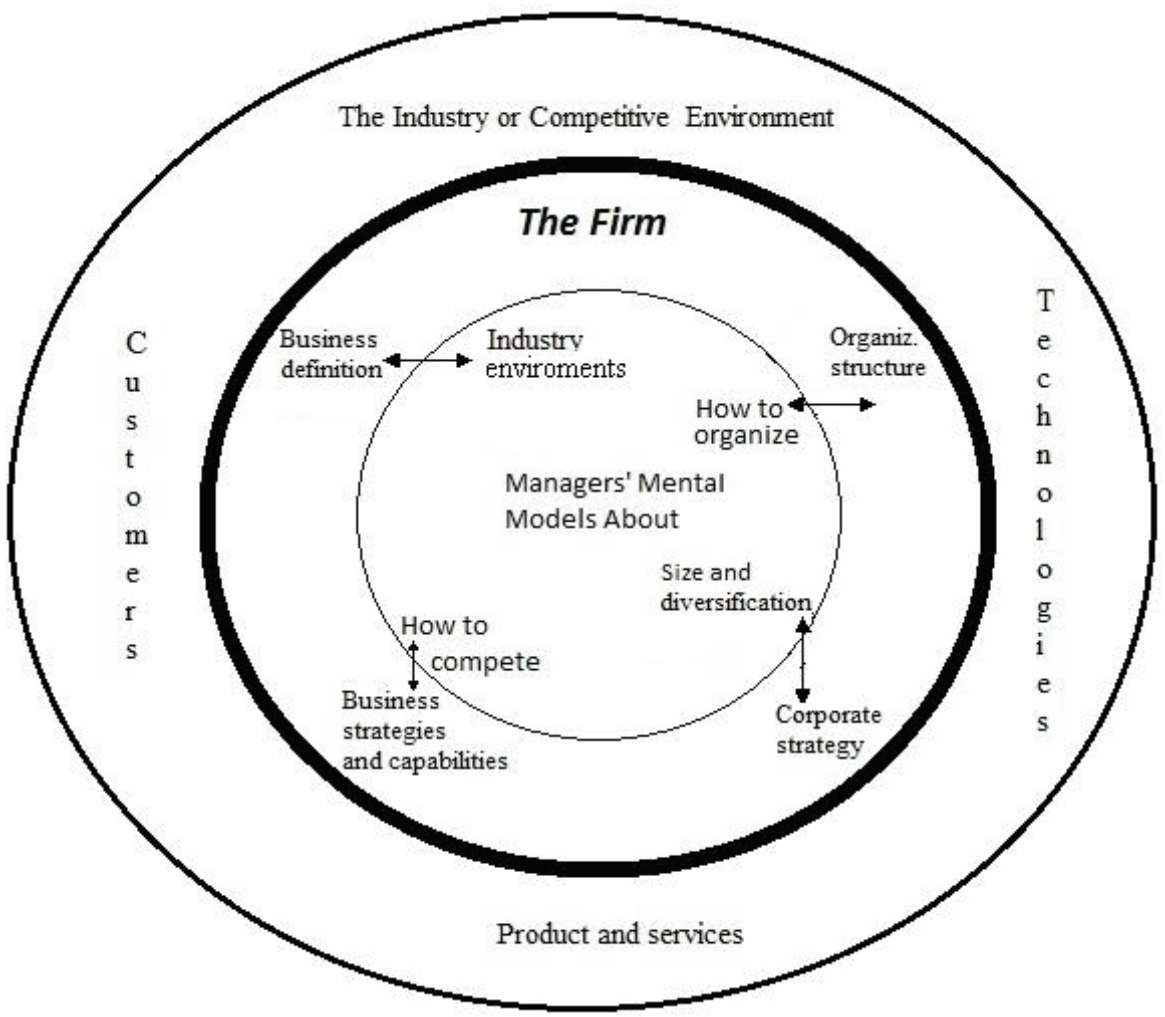

Researchers, S. Kiesler and L. Sproull, have written about the problem of responding to environmental change and have suggested that:

(a) Crucial component of managerial behavior in rapidly changing environments is problem sensing, the cognitive process of noticing and constructing meaning about environmental change so that organizations can take action (Kiesler, Sproull, 1982).

(b) Note the implications of this statement: Noticing is crucial because if changes are not noticed, action will not be taken (Senge, 1990.)

Empirical evidence suggests that managers in current industry environments fail to notice how their industries are changing. How is it possible that experienced and competent managers can simply fail to notice important changes in their organizations environments? Using foresight and anticipation to envisage possible future scenarios is the first step in preparing for change and managing it successfully.

Managers are more committed to their firms ongoing strategies so their ability to recognize unrelated data and other environmental stimuli, are significantly reduced, and so they will "actively ignore" data that are inconsistent with those strategies.

Changes may be happening in their industries, but managers may simply fail to detect these changes because their attention is focused on personal strategies or other related aspects. 
Most research suggests that changes must often be dramatic or have major consequences for firms before their managers will take notice of them. Noticing changes depends on those changes being seen as "breakpoints" (Kiesler, Sproull, 1982). Changes that tend to be noticed are those changes that are significant, sudden, or catastrophic. It seems, unfortunately, when managers and their firms face with significant and sudden changes in their industries, it is often too late for them to respond effectively. Business is declining as a result and some companies never fully recover.

There is a possibility for managers to notice industry changes, but fail to react to them properly so consequences follow. A number of studies suggest also that managers can see changes but find difficulty to understand or interpret problems. For example, a study that examined companies in the declining railroad industry during 1950s and 1960s found that railroad managers noticed or were aware of the significant competitive threat posed by trucks and an improved national highway system by the early 1950s. Those same managers continued to believe that government regulation, the railroad labor unions, and even the weather were more serious problems than competition from trucks (Barr, Stimpert, Huff, 1992, p. 15-36).

Another study compared the financial performance of matched pairs of sample firms from a variety of industries (Cohen, Levinthal,\& Daniel, 1989, p. 128-152). In each pair, one firm went bankrupt while the other firm survived. As illustrated in Figure 2.

Figure 2: Survivors versus Bankrupts-Return Assets in Years Prior to Bankruptcy

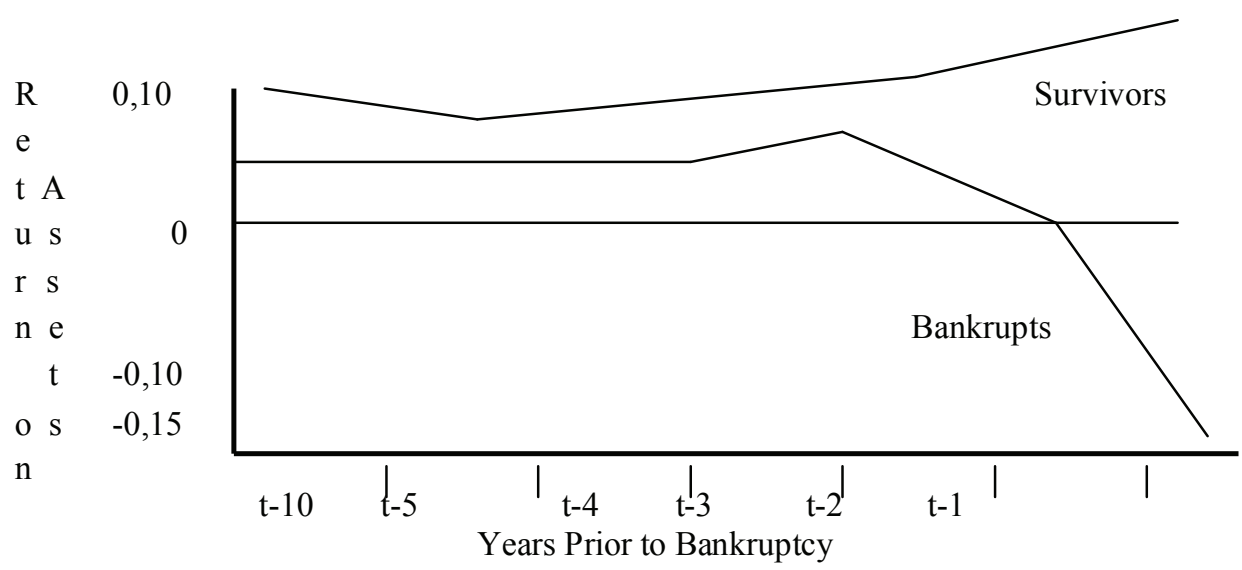

Managers of the low performing firms are certainly noticed that their companies have failed in the race with competition, given such a long lead time, were the managers of the low performing firms unable to formulate and implement strategies that would have changed the course of their histories and avoided eventual bankruptcy? And, in the case of the railroads, why did given managers awareness of the potential threats continue to focus their attention on other factors, such as government regulation and the weather? Possible explanation for this kind interpretation is that manager's mental models will allow them to rationalize away unfavorable stimuli. 
The managers of troubled firms might therefore be able to overlook poor performance on one dimension (say, return on assets), but they can be focused instead on some more positive dimension of performance (such as an increase in sale). As far as railroads are concerned, their business decline was relative rather than absolute. Railroad managers ignored market share losses and took consolation in handling increasing freight volumes even when truck competition increased. Similar thing happened with General Motors and company's share in the US automobile market when declined from over 50 percent in 1980 to only about one-third of the market a decade later. During most of the 1980s, General Motors enjoyed record profits. Because of that, consequences of losing market share were ignored by the managers.

\section{Effective action and fast respond}

Even when managers are fully aware and recognize the seriousness of the changes that are occurring in their competitive environments, they may still have difficulties to formulate appropriate responses or strategies to prevent these threats. A good example how to successfully deal with this problem is Kodak. Kodak's leadership equipped themselves with the adequate flexibility needed to respond quickly to business environmental changes.

We have already mentioned the cognitive factors, besides them there are learning issues. Failures in organizational learning also limit organizational adoption and ability to change. Here, we examine one of the most important organizational learning issues, the distinction between lower-level learning and higher-level learning. Lower-level learning is characterized by improvements or refinements of existing beliefs, understandings, and organizational processes. Higher-level learning involves developing completely new beliefs, understandings and organizational processes.

As illustrated in Figure 3. lower - level learning leads to refinements of existing organizational knowledge and processes that allow firms to reduce unit costs as cumulative output increases. Problems arise when company managers emphasize lowerlevel learning at the expense of higher-level learning. Companies made significant improvement within the activities they are engaged in, but risk failure to develop new abilities, products, services and new technologies to compete.

Figure 3: An Illustration of Experience Effects

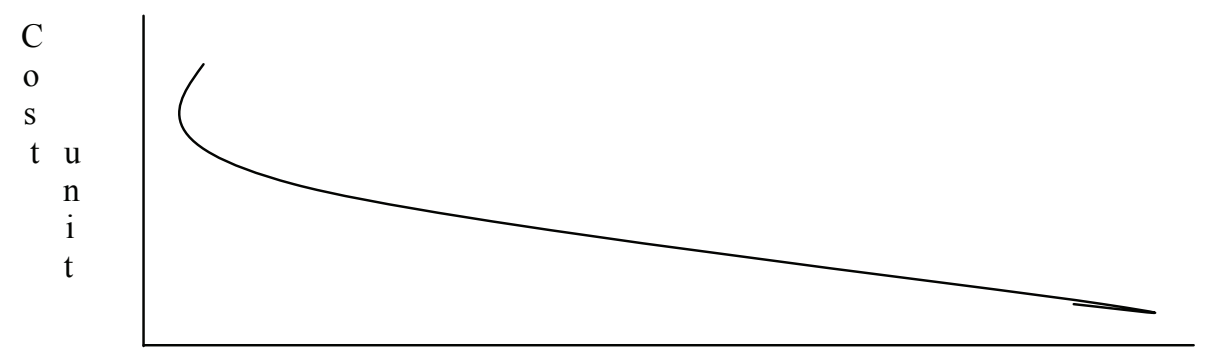

Cumulative Out 
Most companies allocate the majority of resources to lower-level learning rather than higher-level. That allocation is clearly harmful but managers have good reasons to make that decision. Low-level learning has a predictable and positive impact on performance. High-level learning is more likely to have those effects on financial performance in bottom line. Lower-level learning is based on improving current work, while higher-level learning might take whole new ways, markets and strategies.

The exploration of the new, in Kodak's case, their attempts to improve technologies order to develop new products, typically requires considerable investments and often results in financial losses for many years before firms see some significant benefits. Financial instruments for maintaining business success of the company in terms of crisis are varied. They have impact at the material content in the company's balance, its financial position and financial result.

There is another factor that is important to the success of higher-level learning efforts is absorptive capacity (Cohen, Levinthal, 1989. p. 128), which has been defined as the ability of firms to "recognize the value of new information, modify and apply it to commercial ends." (Schneider, 1987, p. 439). High absorption capability companies have a better view on external environments. They can recognize new technology, and use that knowledge in the organization. Firm absorptive capacity is determined by the organization ability to recognize new developments.

\section{A-S-A Cycle (Attraction-Selection-Attrition)}

There is another important factor that limits the ability of a genuine response to change in business world is homogeneity in thinking among managerial structures. Many large organizations are caught in an "Attraction-Selection-Attrition" cycle (illustrated in Figure 4.) that tends to promote homogeneity in opinion managers. (Finkelstein, Hambrick, 1996),

Figure 4: The Attraction-Selection-Attrition (A-S-A) Cycle

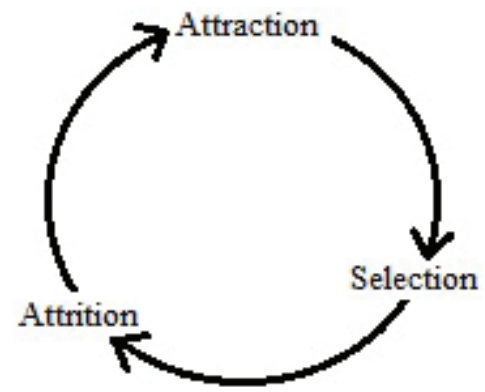

Certain people are attracted to particular firms according to the model. Companies will select among those who has already been attracted, primarily on the basis of "fit", a limited number of individuals to join. Those employees who think that they do not "fit" with these companies will are likely to leave. The A-S-A cycle therefore predicts that the thinking of employees within their responsive companies will become more and more homogeneous over time. 
Although this "thinking alike" can certainly facilitate rapid decision making, it can also have very serious negative consequences for firms operating in fast-changing environments. A management team composed of "alike thinking" individuals has much more chances to avoid to notice important environmental changes or to misinterpret the nature of those changes. Companies can overcome the trap of similar opinion in at least two ways. One would be to pay attention on contrarian voices. Within nearly all organizations there are managers and employees whose ideas are at odds with the prevailing opinion. These individuals and their ideas tend to be ignored, and pushed aside. It is precisely these contrarian members ones who can see aspects of changing industry environments that are ignored by top managers, and they are feel obligations to suggest new ideas and strategies for coping with these industry changes. A second way organizations can overcome the dangers of like-minded would be to encourage the greater turnover among top management ranks. Most research in this matter has focused on the negative organizational consequences (such as the loss of skilled employees and recruiting and training costs) of turnover among lower-level employees. Some studies suggest, however, that a lack of turnover among top managers can have a negative impact on organizations. Studies have shown that executives become more and more committed to the status quo as they remain in the same industry (March, 1991, p. 71). Companies with the same executives are risking pusrsuing strategies that don't work in their industry enviroments.

The choice of an appropriate strategy and its realization through the development and business policy needs to make profit. Profit appears as the aim and purpose of the establishment, ongoing business of the enterprise development and its business and organizational components. (Djordjevic, 2010, p. 214-216).

Introducing new individuals into an organization is valuable not because of their superior knowledge; In fact, this same study asserted that organizational veterans almost always have more knowledge. New employee certainly doesn't have knowledge as experienced managers, but what they know is less redundant, is often insightful, and offers more opportunities for improving existing routines or suggesting new procedures. (Hambrick, 1982. p, 156.)

\section{Different approaches and its role}

Using the same practice can bound organizational changes. Companies operating in the industry also developed a common language and similar understandings about how to compete. Managers of these firms develop a "common body of knowledge" that is reinforced by reading the same publications, participating in professional networks and trade associations, moving across firms.

This institutional context in which firms compete will reinforce existing patterns of competition and firms seeking to adopt new strategies will have to contest industry norms and influences. Companies that deviate from these industry standards - by introducing totally new products and services or by incorporating totally new technologies - will experience considerable upside, but also significant downside, risks. A lot of companies choose to make small product changes or service offerings. Account of organizations struggling to formulate totally new strategies suggest that the process is a very painful 
and highly uncertain, characterized by periods in which organizations are "grouping" or "in flux" without a clear definition or focus. Consequently, many firms choose to pursuing strategies that are consistent with industry norms rather than face the ambiguity and uncertainty associated with formulating and implementing totally new strategies. Few factors can slow manager reactions and limit their ability to anticipate changes in the business environment. These factors include:

1. Cognitive limitations and problems associated with noticing and interpreting, and responding to ambience change,

2. The tendency managers to emphasize low-level learning over high-level learning,

3. The tendency for organizational hiring and promotion practices to foster homogeneity in thinking among managers, and

4. The power of institutionalized industry practices to focus managerial attention on the status quo.

\section{Recapitulation}

Senior managers, not industry forces, are a much more important for organizational success. Managerial thinking, more than industry structure, influences the choice of strategies that allow high performing firms either to occupy unique positions in their competitive arenas or to possess unique competencies that cannot be easily replicated by their rivals.

Business evaluation study is focusing on evaluation, financing, and investment accounting in physical assets. Investing in physical assets are less important than the managers think. The relative importance of managerial thinking, organizational learning, and other intangible organizational assets will almost certainly continue to increase in the years ahead. The obvious fact is that managers need to force studies and organizational changes. We have argued that managers must pursue two types of learning and initiate two types of organizational change. Managers must pursue what they already know which means, they must apply and refine existing knowledge in order to develop the capabilities and competencies that will provide to their firms a competitive advantage. Simultaneously, they must focus on "exploring the new" in order to initiate change and redefine their business and develop the capabilities and competencies that will be needed to enjoy a competitive advantage in the future. Unfortunately, a good deal of facts offered in this paper suggest that managers prefer known over speculative unknown.

\section{References}

Barr, P. S., Stimpert, J. L., \& Huff, A. S. (1992). Cognitive change, strategic action, and organizational renewal. Strategic management journal, 13(S1), 15-36.

Cohen, W. M., \& Levinthal, D. A. (1990). Absorptive Capacity: A New Perspective on Learning and Innovation. Administrative Science Quarterly, 35(1), 128-152.

Coulter, M., (2002), Strategic Management in Action, second edition, Prentice -Hall, New Jersey 
Daily, C. M., McDougall, P. P., Covin, J. G., \& Dalton, D. R. (2002). Governance and strategic leadership in entrepreneurial firms. Journal of management, 28(3), 387-412.

Djordjević, B., (2010), The Third Dimension of Management, University "Union”, Beograd,

Hambrick, D. C. (1982). Environmental scanning and organizational strategy. Strategic Management Journal, 3(2), 159-174.

Finkelstein, S. and D.C. Hambrick, (1996), Strategic Leadership; Top Executives and Their Effects on Organizations. St.Paul: West Publishing

Freed R. D., (2009), Strategic Management - Concept and Cases, Twelth Ed., Perason Education,

Kanton, Dz., (2009), Ekstremna budućnost, Clio, Beograd

Kiesler, S., \& Sproull, L. (1982). Managerial Response to Changing Environments: Perspectives on Problem Sensing from Social Cognition. Administrative Science Quarterly, 27(4), 548-70.

March, J. G. (1991). Exploration and exploitation in organizational learning. Organization science, 2(1), 71-87.

Mintzberg, H. (1978). Patterns in strategy formation. Management science, 24(9), 934-948.

Senge, P.M., (1990), The Fifth Discipline: The Art and Practice of the Learning Organiuzation, NewYork: Doubleday/ Curency

Schneider, B. (1987). The people make the place. Personnel psychology, 40(3), 437453.

http://citeseerx.ist.psu.edu/viewdoc/download?doi=10.1.1.457.6815\&rep=rep1\&typ $\mathrm{e}=\operatorname{pdf}(15.03 .2015)$ 